\title{
This Is Not a Drill
}

\section{Notes on Surviving the End of the World, Again}

\author{
Jamaica Heolimeleikalani Osorio
}

All I know:

The ships came

And my people started dying.

1778.

All I know:

The ships came

And my people started dying.

2020.
All I know:

This anxiety and grief is new

And ancient.

All I know:

My Kūpuna survived too much

for us to be taken out like this.

On January 13, 2018, Hawai' $i$ awoke to the message: "BALLISTIC MISSILE THREAT INBOUND TO HAWAII. SEEK IMMEDIATE SHELTER. THIS IS NOT A DRILL." We shook ourselves and braced for impact for thirty-eight minutes, until notified via Twitter there was no inbound missile.

On March 11, 2020, the World Health Organization declared the vicious spread of COVID-19 a pandemic. At the end of August 2020, over 25,000,000 cases have been confirmed, resulting in over 840,000 deaths worldwide (World Health Organization). Hawai' $i$ has endured a less staggering impact-8,339 confirmed cases and sixty-three deaths (State of Hawai'i). Over the past month I have watched many of my people struggle between their desire to return to a life that resembles normalcy and the reality of a second wave of COVID-19 spreading across our pae 'anina. When you couple this with the fact that a ballistic missile was never actually fired, one might believe that Hawai'i escaped the full trauma of these two events. I cannot help but feel, however, that considering them in relation to Hawai'i's history of mass death and displacement is already having a profound impact on how our lāhui will imagine and practice pilina into our future. Like the great dying of my kūpuna in the eighteenth and nineteenth centuries, these recent events have exposed many of the ways that colonialism has foreclosed so many of our futures and possibilities. Our population collapse, the missile crisis, and COVID-19 each represent a kind of ending. I would suggest, however, that if we are careful and intentional, they can also inspire a kind of beginning. 
I begin with two simple questions. What does it means to live in the wake of these life-altering events? And how will they shape our experience as Kānaka Maoli, as we navigate what it means to live in ethical pilina to each other and our 'äina? These questions are inspired by the work of Black futurists, who remind us that the "Apocalypse already happened: that (in Public Enemy's phrase) Armageddon been in effect" (Sinker), and Indigenous resurgence scholars, who reframe Indigenous "tension over membership and belonging" as a "fear of disappearing" (Simpson 176). While continuing to feel the ghost of mass death in our bones, we contemplate what it means to be terrified of our own extinction. As Kānaka Maoli, we know that our world has ended many times before, but because of the resilience of our kūpuna, it has begun "again in the morning" (Waheed). What will it take to begin again now, in ways that open futures, rather than continue to foreclose them?

My work is concerned with how aloha aaina articulates certain norms of Hawaiian intimacy and behavior long disrupted by forces of colonialism such as capitalism, patriarchy, and white supremacy. But so far, I've paid little attention to how mass death has also disrupted our networks of relations. So the first thing I learned from COVID-19 is that it is very hard to understand and articulate the intergenerational trauma you carry until you've been triggered. And if nothing else, these two events, the missile and the virus, are extreme examples of a cultural, communal triggering.

I am not a political strategist. I do not know how to end the mass accumulation of weapons and military strength that leaves most of the world vulnerable to displacement, disfigurement, and death. I am not an economist. I do not know how to revive our plundered economy, or to restore health and wellness to our communities in the wake of these events. But I do know enough about history and mo'olelo to be sure that returning to the status quo cannot be an option for those of us caught under the weight of the will of American and European imperialism and globalization. I know that national security has never resulted in genuine security for our people, and that the "essential" services our government has identified in the wake of this pandemic were never meant to meet the essential needs of our people. I know that when Governor David Ige instated the shelter-in-place order, I felt a kinship to my kūpuna that I had never experienced before. We have all been given a glimpse of what it means to be struck by a ma' $\mathrm{i}$ ka'awale (separating sickness) that neither we or Kaluaiko'olau can ultimately outrun. But I also know that when Ko'olau defied the orders to be taken to Kalalau alone, and fled the forces of the Provisional Government, he was not running away from exile but toward his 'ohana.

When our people desperately attempt to escape our death, disappearance, and extinction, we have always run toward something-usually each other-rather than escaping into isolation. In essence, without the survival of our 'äina and lāhui, our individual survival is meaningless.

Few moments have displayed this as clearly as the rise of the Hui Aloha 'Āina in the late 1890s and the rise of our mighty wave in 2019. Our kūpuna gathered the 
kū'è petitions at the rock bottom of our population collapse. A once widespread and growing population of over 800,000 was then a mere 33,000 (Act of War). And still, aloha 'āina's magnetic force bound our people together in action.

This was also true for how our people gathered and united just a year ago to protect our Sacred Mauna a Wākea. One of the greatest lessons I learned during our time as a lāhui on the Mauna was that when we are grieving, and aspiring for something better, these feelings come with an intense, even desperate longing to be pilina with each other. We gathered in the thousands at 7,000 feet-in the bitter cold and sweltering heat, with the threat of arrest and physical harm always with us. Another lesson I am learning from all of our mo'olelo is that we passionately wish to create and live in a better future. But more than that. We desperately want to walk into that future together. This is why, in the absence of proper institutions of care in this time of COVID-19, our people have developed grassroots initiatives to feed our communities, to educate our keiki, and to revive our economy. ${ }^{1}$

In 2020, among our greatest challenges will not be just creating a new economy, or reimagining a more ethical health system, but also taking seriously how we will hold closely to each other in this time of great vulnerability. The truth is, the desire to return to "normal" ways of being in pilina with each other could be what brings about our demise. At a time when our leadership will not put the health and needs of our people before the wealth and desires of tourists and big business, we must confront our need to reimagine what it means to be in pilina. Since nearly everything we know about pilina demands showing up — to our 'āina, to each other-are we ready to reimagine our most sacred and routine ceremonies and rituals? Will we commit to new ways of practicing aloha when our survival depends on it?

I believe we are up to this challenge of creating a new world, or continuing to "live in the future," as Bryan Kuwada has written. But I also believe this will require us first to come face-to-face with our grief. We must understand how deeply the vicious and violent cycle of history has affected us. Our healing will become possible only when we acknowledge all the endings we have survived-the coming of ships, the spreading of death, the taming of industry, the carving of land, crosses, and cultures.

And I'd also suggest that the 2018 missile threat, the 2019 arrest of our Küpuna, and the 2020 spread of COVID-19 are further traumas we must intimately engage, as we imagine who we are in the face of all these endings.

\section{Note}

1. See 'Āina Aloha Economic Futures (https://www.ainaalohafutures.com/) and Building Bridges, Not Walking on Backs: A Feminist Economic Recovery Plan for COVID-19 (https://humanservices.hawaii.gov/wp-content/uploads/2020/04/ 4.13.20-Final-Cover-D2-Feminist-Economic-Recovery-D1.pdf). 


\section{Works Cited}

Act of War: The Overthrow of the Hawaiian Nation. Produced by Puhipau and Joan Lander. Nā Maka o ka 'Āina, 1993.

Kuwada, Bryan Kamaoli. "We Live in the Future. Come Join Us." Ke Kaupu Hehi Ale, 3 April 2015, https://hehiale.wordpress.com/2015/04/03/we-live-in-the-future-come-join-us/.

Simpson, Leanne Betasamosake. As We Have Always Done: Indigenous Freedom through Radical Resistance. U of Minnesota P, 2017.

Sinker, Mark. "Loving the alien in advance of the landing-Black science fiction." The Wire, no. 96, Feb.1992.

State of Hawai 'i, Department of Health. "Disease Outbreak Control Division | COVID-19," https://health.hawaii.gov/coronavirusdisease2019/.

Waheed, Nayyirah. Salt. CreateSpace, 2013.

World Health Organization. "WHO Coronavirus Disease (COVID-19) Dashboard," https://covid19.who.int.

Dr. Jamaica Heolimeleikalani Osorio is a Kanaka Maoli wahine activist, writer, and scholar from Pālolo, O'ahu. Currently, Heoli is an Assistant Professor of Indigenous and Native Hawaiian Politics at the University of Hawai' $i$ at Mānoa. Heoli is a three-time national poetry champion, poetry mentor, and a published author. She is a proud past Kaiāpuni student, Ford Fellow, and a graduate of Kamehameha Schools, Stanford University (BA), New York University (MA), and the University of Hawai i i at Mānoa (PhD). 